\title{
Proteomic Profiling of Ovarian Cancer Plasma using Immunoaffinity Depleted Plasma and Two-Dimensional PAGE
}

\author{
Karen T. Oliva - Mustafa Ayhan - Gillian Barker • \\ Nicole L. Dellios • Michael A. Quinn • Gregory E. Rice
}

Published online: 27 November 2007

(C) Humana Press Inc. 2007

\begin{abstract}
Objective The aim of this study was to evaluate a multiple immunoaffinity protein depletion (multiple affinity removal system, MARS) pre-treatment strategy with subsequent two-dimensional polyacrylamide gel electrophoresis (2D PAGE) and peptide mass finger printing analysis for the detection of ovarian cancer-associated plasma proteins.

Materials and Methods Following immunoaffinity depletion, total plasma protein content was reduced by $84.2 \pm$ $1.8 \%$ (mean $\pm \mathrm{SE}, n=32$ ). The number of proteins detected in the control and ovarian cancer groups was 349 and 357, respectively. This represented an increase in spot detection of almost twofold when compared to 2D PAGE displays of untreated plasma (174 spots). Of the proteins displayed, post-depletion, 300 (control) and 302 (ovarian cancer, OC) were common within each group. PDQuest analysis indicated that 109 protein spots were statistically different between the two groups and, of these, 59 exhibited greater than or equal to twofold difference in spot density (Student's $t$ test, $p=0.01$ ). Thirty-nine of these proteins were successfully identified with reliable confidence.

Results and Discussion The data obtained in this study demonstrates that immunodepletion of plasma before $2 \mathrm{D}$
\end{abstract}

K. T. Oliva $\cdot$ M. Ayhan · G. Barker • N. L. Dellios $\cdot$ G. E. Rice Translational Proteomics, Baker Medical Research Institute, Melbourne, Victoria 3004, Australia

\section{A. Quinn}

The Royal Women's Hospital,

Carlton, Victoria 3134, Australia

K. T. Oliva $(\triangle)$

Translational Proteomics, Baker Medical Research Institute,

P.O. Box 6492, St Kilda Road Central,

Prahran, Victoria 8008, Australia

e-mail: karen.oliva@baker.edu.au
PAGE profiling have generated identifiable plasma proteins that are differentially expressed in the high-grade ovarian cancer sample set compared to controls. This approach, therefore, may be useful in identifying candidate biomarkers for inclusion in multi-marker tests for ovarian cancer that may exhibit greater sensitivity and specificity than those currently available. It was evident, however, from the predominant identification of host response proteins that immunodepletion did not generate sufficient levels of enrichment of lower abundance tumor-specific proteins to facilitate detection.

Keywords Biomarker - Mass spectrometry .

Multiple affinity removal system (MARS) .

Ovarian cancer (OC) · Two-dimensional polyacrylamide gel electrophoresis (2D PAGE)

\section{Introduction}

Almost 1,500 new cases of ovarian cancer were diagnosed in Australia in 2006. The relative 5-year survival rate for women diagnosed with ovarian cancer from 1998 to 2002 was $42 \%$, predominantly because of diagnosis at an advanced stage. An overall 5-year survival rate of $95 \%$ can be achieved, however, if ovarian cancer is detected early. The asymptomatic nature of the disease and the low sensitivity and specificity of the currently available test utilizing CA-125 present a major challenge for achieving early detection [1].

Proteomic profiling has afforded insights into diseaseassociated changes in protein expression and may prove its utility in identifying ovarian cancer biomarkers [2-4]. Limitations of the proteomic profiling of human plasma have been the interference from high-abundance proteins 
(including albumin, IgGs, and clotting cascade proteins). Previously, solid-phase, affinity-based chromatographic methods, such as Affigel-blue ${ }^{\circledR}$ and Affigel ${ }^{\circledR}$ Protein A, have been used to remove such proteins from plasma [5, 6]. Recently, immunoaffinity approaches have been developed to remove high-abundance proteins and enhance the detection and characterization of low-abundant proteins in human plasma [7-11]. For example, Bjorhall et al. [9] used five different depletion columns to investigate efficiency, specificity, and reproducibility of the techniques. They concluded that the MARS column was the most specific and reproducible. Martosella et al. [10] used a combination of immunodepletion (MARS) and reversed phase highperformance liquid chromatography (HPLC) fractionation to produce higher quality protein identifications.

The use of MARS for plasma depletion and subsequent identification of diagnostic biomarkers from this study is fundamental to early detection of ovarian cancer with the expectation of enhanced efficiency of treatment and a subsequent increase in the rate of survival as the principal objective.

The hypothesis to be tested in this study was that immunodepletion of six high-abundance proteins from plasma before two-dimensional polyacrylamide gel electrophoresis (2D PAGE) display would enhance the detection and identification of disease-associated changes in ovarian cancer plasma proteins.

\section{Materials and Methods}

\section{Human Plasma Samples}

The study was approved by the Royal Women's Hospital, Research and Human Ethics Committee, Melbourne, Australia. Participant information statements were provided, and informed consent was obtained before sample collection.

Blood samples were obtained by venipuncture of healthy female volunteers $(n=16)$, patients with benign ovarian neoplasm $(n=8)$, and patients with grade 3 ovarian cancer ( $n=16,12$ serous and 4 clear cell carcinoma), with collection in a 7.5-ml vacutainer (Sarstedt, Numbrecht, Germany) containing lithium heparin as an anticoagulant. Blood samples were centrifuged $\left(2,000 \times g\right.$ at $\left.4^{\circ} \mathrm{C}\right)$, and the separated plasma was aliquoted and stored at $-80^{\circ} \mathrm{C}$ until further analysis.

\section{Depletion of High-Abundant Proteins}

\section{Affinity Column}

The human multiple affinity removal system (MARS) used in this study was a solid phase immunoaffinity column
(4.6 $\times 50 \mathrm{~mm}$, Agilent Technologies, Wilmington, DE, USA) containing monoclonal antibodies targeting albumin, IgG, anti-trypsin, IgA, transferrin, and haptoglobin. Sample processing was performed using an Agilent 1100 HPLC system and proprietary reagent solutions (Agilent).

\section{Sample Preparation}

Human plasma was diluted fivefold with buffer A (a proprietary neutral buffer, $\mathrm{pH} 7.4$, containing salt) to which a protease inhibitor cocktail (mini-complete, Roche Biochemicals, Indianapolis, IN, USA) was added. The sample was then filtered through a $0.22-\mu \mathrm{m}$ spin tube (Agilent Technologies, Wilmington, DE, USA) and centrifuged at $16,000 \times g$ for $1 \mathrm{~min}$ to remove particulates. Diluted plasma was stored at $4^{\circ} \mathrm{C}$. The sample $(100 \mu \mathrm{l})$ was injected onto the MARS column in $100 \%$ buffer $\mathrm{A}$ at a flow rate of $0.25 \mathrm{ml} / \mathrm{min}$ for $9 \mathrm{~min}$. Flow-through fractions, containing the lower abundant proteins (LAP) that did not bind to the column, were collected in 96 well plates (Greiner Bio-One BioScience, Frickenhausen, Germany) and stored at $4^{\circ} \mathrm{C}$ within the thermostat-controlled fraction collector. The bound fractions or high-abundant proteins (HAP) were eluted with $100 \% \mathrm{~B}$ at a flow rate of $1.0 \mathrm{ml} / \mathrm{min}$ for $3.5 \mathrm{~min}$. The column was regenerated and equilibrated with $100 \%$ buffer A for $7.5 \mathrm{~min}$. The total time for each depletion experiment was $20 \mathrm{~min}$. Protein elution profiles were monitored at a wavelength of $280 \mathrm{~nm}$.

\section{Buffer Exchange/Solvent Exchange}

Depleted plasma samples were concentrated using Amicon Ultra 5000 Dalton molecular weight cut-off centrifugal devices according to manufacturer's instructions (Millipore Corporation, Billerica, MA, USA). The solvent was exchanged by reconstituting the retentate to the original sample load volume using $20 \mathrm{mM}$ phosphate buffer, $\mathrm{pH}$ 7.6. This process was repeated three times.

\section{Protein Concentration Determination}

Total protein content of each sample was determined using the Coomassie Plus protein assay reagent kit according to manufacturer's instructions (Pierce Biotechnology, Rockford, IL, USA) using bovine serum albumin as the standard.

Sample Pre-Conditioning for 2D PAGE Analysis

MARS depleted samples were preconditioned for 2D PAGE analysis using a 2-D clean-up kit according to manufacturer's instructions (GE Healthcare Bio-Sciences, Uppsala, Sweden). Protein concentration was redetermined after preconditioning. 
Two-Dimensional Gel Electrophoresis

A total of $40 \mu \mathrm{g}$ protein was loaded onto first-dimension Ready Strip ${ }^{\mathrm{TM}}$ gels $(11 \mathrm{~cm}, \mathrm{pH}$ 4-7; Bio-Rad Laboratories, Hercules, CA, USA) after sample solubilization with multiple chaotrope solubilization solution $[200 \mu \mathrm{l}, 7 \mathrm{M}$ urea; $2 \mathrm{M}$ thiourea; $100 \mathrm{mM}$ dithiothreitol (DTT); 4\% CHAPS; $40 \mathrm{mM}$ Tris buffer; $0.5 \%$ carrier ampholytes, pH 4-7; trace bromophenol blue] as previously described $[5,6]$. Second dimension separation was performed on precast $10 \%$ Tris- $\mathrm{HCl}$ criterion gels (Bio-Rad Laboratories) and stained with Sypro Ruby ${ }^{\circledR}$ fluorescent protein dye (Bio-Rad Laboratories). Gels were individually scanned using an FX imager with a 532-nm laser at $100 \mu \mathrm{m}$ resolution (Bio-Rad Laboratories). The protein spots were detected, quantified, and matched using PDQuest V7.3.1 (Bio-Rad Laboratories). Each gel was normalized to the total quantity of valid spots. The gels were then counterstained with colloidal coomassie brilliant blue (CBB) to enable visualization and manual excision.

In-Gel Digestion and Peptide Analysis Using Matrix-

Assisted Laser Desorption-Ionization Time-of-Flight Mass Spectrometry

In this study, a combination of two mass spectrometers (Ettan MALDI-ToF Pro, GE Healthcare; MALDI Autoflex II, Bruker Biosciences) were used to estimate peptide masses generated from the in-gel digestion of the $2 \mathrm{D}$ PAGE protein spots. The database search results and tabulated protein identifications are from a combination of data collected from both mass spectrometers. Only high scoring and confident hits retrieved from the selected databases using Mascot and ProFound ${ }^{\mathrm{TM}}$ search engines are tabulated.

Selected protein spots were manually excised from colloidal CBB-stained 2D gels using a spot picker (The Gel Company, San Francisco, CA, USA, picker head, 1.5$\mathrm{mm}$ diameter). The gel plugs were rinsed by transfer into 96-well plates (Greiner Bio-One BioScience) containing deionized water (100 $\mu \mathrm{l}$ per well, MilliQ grade). Digestion using trypsin with subsequent application to a matrixassisted laser desorption-ionization time-of-flight (MALDIToF) target plate (GE Healthcare and Bruker Biosciences) was performed robotically with an Ettan Spot Handling workstation (GE Healthcare). The gel plugs were destained in $100 \mu \mathrm{l}$ of $50 \mathrm{mM}$ ammonium bicarbonate (Riedel-de Haen, Germany) $/ 50 \%$ methanol (Lab-Scan Analytical Sciences, Ireland) for $30 \mathrm{~min}$, then washed three times in deionized water (100 $\mu \mathrm{l}, 5 \mathrm{mins}$, Milli Q grade). Gel plugs were then incubated in $100 \mu \mathrm{l}$ of $50 \mathrm{mM}$ ammonium bicarbonate $/ 50 \%$ methanol for $30 \mathrm{~min}$ followed by incubation in $100 \mu \mathrm{l}$ of $75 \%$ acetonitrile (ACN, Lab-Scan
Analytical Sciences, Ireland) for a further $30 \mathrm{~min}$. After drying the gel plugs $\left(40^{\circ} \mathrm{C}, 23 \mathrm{~min}\right), 10 \mu \mathrm{l}$ of sequencing grade trypsin solution $(20 \mathrm{ng} / \mu \mathrm{l}$, Promega, Madison, WI, USA) dissolved in $20 \mathrm{mM}$ ammonium bicarbonate was added and incubated $\left(37^{\circ} \mathrm{C}\right.$ for $\left.180 \mathrm{~min}\right)$. During the following extraction step, gel plugs were covered with $60 \mu \mathrm{l} 0.1 \%$ trifluoroacetic acid (TFA, Pierce, Rockford, USA) $/ 50 \%$ ACN and incubated for $20 \mathrm{~min}$. The peptide containing supernatant was transferred to a new 96-well plate, and the extraction was repeated $(40 \mu \mathrm{l})$. The supernatants were pooled and dried $\left(40^{\circ} \mathrm{C}\right.$ for $\left.3 \mathrm{~h}\right)$. The peptides were resolubilized by manually adding 50\% ACN/0.1\% TFA $(15 \mu \mathrm{l})$ into each well and gently vortexing (10 mins., Vortex Genie 2). The resolubilized peptide mixtures $(0.3 \mu \mathrm{l})$ were each combined with MALDI matrix $(1.0 \mu \mathrm{l}$, $\alpha$-cyano-4-hydroxy cinnamic acid, $3 \mathrm{mg} / \mathrm{ml}$ in acetone/ ethanol $(1: 2, v / v)$, Bruker Biosciences) and applied $(1.3 \mu \mathrm{l})$ to the Anchorchip target plate using the Ettan Spot Handling robotic workstation (GE Healthcare). Alternatively, the peptide mixtures were combined with the same MALDI matrix $(1.0 \mu \mathrm{l}, 3 \mathrm{mg} / \mathrm{ml}$ in $50 \% \mathrm{ACN} / 0.1 \%$ TFA, Bruker Biosciences) and applied $(1.3 \mu \mathrm{l})$ to the GE Healthcare target plate using the Ettan Spot Handling robotic workstation (GE Healthcare). The peptide-matrix samples were allowed to dry on the target plates (1015 mins) before data collection using either of the two described MALDI-ToF mass spectrometers.

MS Data Collection, Database Searching, and Protein Identification

General instrument settings for the MALDI-ToF Pro MS (GE Healthcare) are as follows: mode, reflector, and positive ion polarity; $20 \mathrm{kV}$ accelerating potential, $20 \mathrm{kV}$; laser, 8 shots/second (200 shots per spectra); mass range, $800-4,000 \mathrm{~m} / \mathrm{z}$. The instrument was internally calibrated using trypsin autolytic fragments (842.510 and $2211.1046 \mathrm{~m} / \mathrm{z}$ ).

General instrument settings for the Autoflex II MALDIToF/ToF (Bruker Biosciences) are as follows: mode, positive, and reflector; pulsed ion extraction, $120 \mathrm{~ns}$; laser intensity, 22-28\%; laser frequency, $25 \mathrm{~Hz} ; 600$ laser shots were collected and summed for all MS data. The mass range $(800-3,000 \mathrm{~m} / \mathrm{z})$ of the mass spectrometer was internally calibrated using the autolytic peaks of trypsin (842.510 and 2,211.1046 $\mathrm{m} / \mathrm{z})$. Matrix was suppressed using a high-gating factor. Signal suppression below $800 \mathrm{~m} / \mathrm{z}$ was activated. Data acquisition and processing was performed using instrument-specific software, Ettan MALDI-ToF Pro software 2.0 (GE Healthcare) or FlexControl, FlexAnalysis, and BioTools software (Bruker Daltonics). Peaklists were generated before database searching. 
The mass spectral data collected from the MALDI-ToF Pro instrument was submitted to the National Centre for Biotechnology Information nonredundant database (NCBInr, V1.30, 22 March 2006), http://www.prowl.rockerfeller.edu/ prowl-cgi/profound.exe) using the ProFound ${ }^{\mathrm{TM}}$ search engine. Data collected from the Autoflex II MALDI ToF/ToF was submitted to the SwissProt database (release 51.0, 31 October 2006) using the Mascot search algorithm (Matrix Science, http://www.matrixscience.com). Typical search parameters for both search engines were as follows: mass tolerance, $0.5 \mathrm{Da}$; missed cleavages, 2; enzyme, trypsin; fixed modifications, carbamidomethylation; variable modification, Oxidation (M); taxonomy, Homo sapiens.

\section{Results}

\section{High-Abundant Protein Depletion}

Total plasma protein concentration averaged $54 \pm 2.6 \mathrm{mg} / \mathrm{ml}$ $(n=32)$, of which $1.08 \pm 0.02 \mathrm{mg}$ of protein was loaded onto the MARS column. After depletion of HAP, protein concentration averaged $0.17 \pm 0.02 \mathrm{mg} / \mathrm{ml}$, representing an average reduction in total protein content of $84.2 \pm 1.8 \%$ (Table 1, Fig. 1).

\section{D PAGE}

Protein profiles from 16 grade 3 (high-grade) ovarian cancer patient plasma were analyzed, 12 with serous tumors and 4 with clear cell tumors. Sixteen healthy volunteers comprised the control group. Analysis by 2D PAGE was performed and a representation of each group including untreated plasma is shown in Fig. 2. In untreated plasma (Fig. 2a), 174 proteins spots are displayed, and the high-abundance proteins targeted by the MARS column are clearly evident.

After depletion, $349 \pm 26$ spots in the control group and $357 \pm 24$ spots in the OC group were observed.

From the proteins that were displayed after depletion, 172 (normal) and 166 (OC) spots were present in all 16 members

Table 1 Protein budget table of depletion process

\begin{tabular}{lll}
\hline Steps in process & $\begin{array}{l}\text { Protein } \\
\text { content } \\
(\mu \mathrm{g} \pm \mathrm{SE})\end{array}$ & $\begin{array}{l}\text { Percent } \\
\text { of original } \\
\text { protein load }\end{array}$ \\
\hline $\begin{array}{l}\text { Plasma protein content (pre-MARS; } \\
n=32)\end{array}$ & $1,081 \pm 21$ & 100 \\
$\begin{array}{l}\text { Flow-through fractions } \\
\text { containing LAP }(n=32)\end{array}$ & $171.5 \pm 20$ & 15.8 \\
$\begin{array}{l}\text { Concentrated and buffer } \\
\text { exchanged }(n=32)\end{array}$ & $132.1 \pm 11$ & 12.2 \\
$2 \mathrm{D}$ clean-up $(n=32)$ & $52.4 \pm 2.4$ & 4.84 \\
\hline
\end{tabular}

of each group. The overall mean coefficient of variance for all spots was 48 and $56 \%$, respectively, as calculated by PDQuest. A matching summary is provided for each sample in Table 2. Between the two groups, 109 spots were statistically different, and of these, 59 were differentially expressed greater than or equal to twofold (Student's $t$ test, $p=0.01$, Fig. 2b,c). Thirty-nine of these proteins have been identified with high confidence (Tables 3 and 4).

Proteins bound to the MARS column were subsequently eluted and also separated by 2D PAGE (Fig. 2d).

In addition to comparing grade 3 ovarian cancer with normal MARS-depleted plasma protein displays, plasma collected from patients with benign ovarian neoplasm were compared with eight matched plasma samples from normal women. This comparison allowed the identification of proteins differentially and exclusively expressed in association with grade 3 ovarian cancer.

A representation of the protein profile from eight benign ovarian neoplasm patients post-HAP depletion and subsequent 2D PAGE is displayed in Fig. 2e.

\section{Protein Identification}

Ettan MALDI-ToF Pro MS spectral peaklists were submitted to NCBI non-redundant database using ProFound ${ }^{\mathrm{TM}}$. The Bruker Autoflex II MALDI ToF/ToF spectral peaklists were submitted to the SwissProt database using Mascot. Proteins with an expectation (probability) of $<0.05$ (indicating a $5 \%$ statistical probability that the protein is a random hit) was the criteria used for reporting results retrieved with ProFound. Probability-based Mowse scores greater than 54 were deemed significant $(p<0.05)$ when reporting search results retrieved with Mascot.

\section{Discussion}

The hypothesis to be tested in this study was that immunodepletion of six high-abundance proteins from plasma before 2D PAGE display would enhance the detection and identification of disease-associated changes in ovarian cancer plasma proteins. The data obtained support this hypothesis in that removal of high-abundance plasma proteins enriched residual proteins by an order of magnitude and enabled the identification of differentially expressed ovarian-cancer-associated proteins. The spot density of 59 protein spots was greater than or equal to twofold difference between displays of normal and ovarian cancer samples (Student's $t$ test, $p=0.01$ ). Of these spots, 39 were confidently identified by peptide mass fingerprint analysis. Proteins previously reported to be associated with ovarian cancer were identified in plasma obtained from women with high-grade tumors. 
Fig. 1 Representative chromatogram of $4.6 \times 50 \mathrm{~mm}$ column depicting fractionation of a human plasma sample into low-abundant proteins and highabundant proteins. Arrows indicate representative peaks

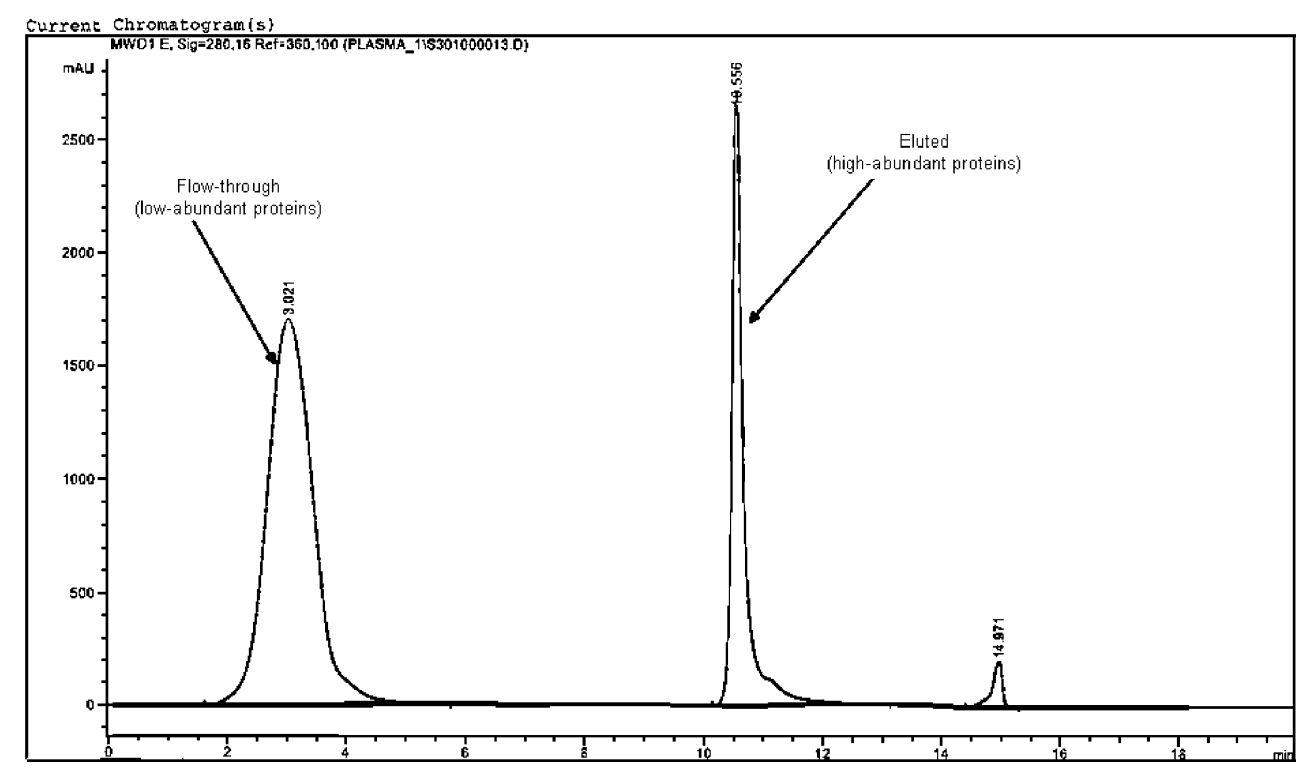

Fig. 2 2-D gel images of MARS-treated plasma from both the control and the cancer samples separated on $\mathrm{pH}$ 4-7 strips and then resolved on $10 \%$ gels. Protein load was $40 \mu \mathrm{g}$ for depleted plasma and $25 \mu \mathrm{g}$ for both neat and HAP. a Representative protein profile from a neat plasma sample. b Representative protein profile from a depleted control sample. Proteins that are down-regulated are depicted in yellow. c Representative protein profile from a depleted cancer sample. Proteins that are up-regulated are depicted in red. d Representative protein profile from a depleted plasma sample depicting the HAP fraction only.

e Representative protein profile from a depleted benign ovarian neoplasm sample. Proteins that are down-regulated are depicted in yellow; proteins that are upregulated are depicted in red
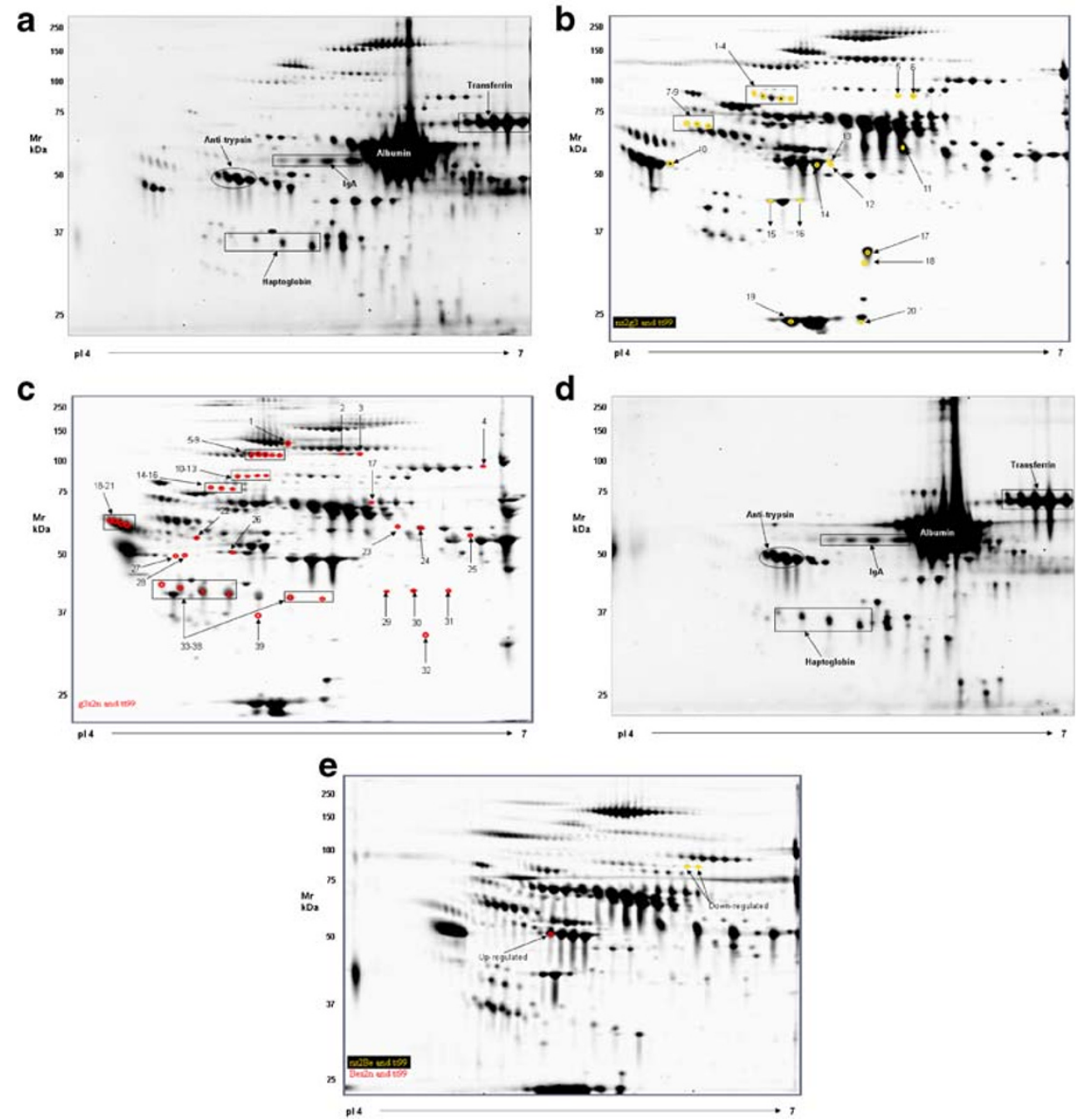
Table 2 Matching summary from PDQuest analysis of normal $(n=16)$ and cancer $(n=16)$ depleted plasma

\begin{tabular}{llllll}
\hline Plasma sample & $\begin{array}{l}\text { Spot number } \\
\text { mean } \pm \text { SD }\end{array}$ & $\begin{array}{l}\text { Spots matched (to master) } \\
\text { within replicate group }\end{array}$ & $\begin{array}{l}\text { Matched to all within } \\
\text { match set }\end{array}$ & $\begin{array}{l}\text { Number of spots } \\
\text { down-regulated }\end{array}$ & $\begin{array}{l}\text { Number of spots } \\
\text { up-regulated }\end{array}$ \\
\hline Normal $(n=16)$ & $349 \pm 26$ & $300 \pm 30$ & 172 & NA & NA \\
Grade $3(n=16)$ & $357 \pm 24$ & $302 \pm 22$ & 166 & 20 & 39 \\
\hline
\end{tabular}

The data set that relates to benign ovarian neoplasm demonstrated that with the exception of three proteins exhibiting greater than or equal to twofold difference in spot density (Student's $t$ test, $p=0.01$ ), the protein display profiles are identical to the control group. None of the three proteins identified represent any of the 59 proteins that were found to be statistically different between the control and cancer groups. These data further support and validate the utility of the observed differential expression of proteins we identified in the late-stage disease group.

As immunodepletion only reduced total plasma protein content by $82 \%$, it is more probable that differentially expressed proteins identified represent high-abundance host response proteins rather than from the tumor tissue. Indeed, most of the proteins identified may be classified as proteins affected by or intrinsic to the acute phase and/or inflammatory response. While this does not negate the potential utility of such candidate proteins in multi-marker, multiplex assays for ovarian cancer, it may impact on disease specificity of such tests.

Of the ovarian-cancer-associated proteins identified, afamin and vitamin D-binding protein are members of the albuminoid gene superfamily and were both found to be under expressed in OC. These findings are supported by previous studies where afamin had been shown to be a specific binding protein for vitamin $\mathrm{E}$ known to be essential in protecting against oxidative damage and disease [12]. Further supporting these findings, $\mathrm{Wu}$ et al. showed that the levels of afamin in hepatocellular carcinoma are significantly reduced when compared to normal hepatocytes [13], and a study from Cancer Research UK Clinical Centre also confirmed that patients with ovarian cancer have decreased levels of afamin and stated that, when used in conjunction with CA125, it may have the potential as a clinical marker of ovarian cancer [14].

Previously, Huang et al. investigated serum obtained from patients with breast cancer and control subjects utilizing 2D PAGE and MS and reported that hemoglobin was up-regulated in cancer patients. Notably, haptoglobin functions as a scavenger of hemoglobin and the increase in serum haptoglobin levels observed in this study may be consequential to the amplification in the level of the protein [15]. The data obtained in this study support previous observations that haptoglobin expression is increased in the serum of grade 3 ovarian cancer patient when compared to control serum [5]. It is important to note that the binding

Table 3 Protein characterization of proteins down-regulated

\begin{tabular}{|c|c|c|c|c|c|c|c|c|}
\hline Spot no. & Database retrieved identity & $\begin{array}{l}M_{\mathrm{r}} \\
(\mathrm{kDa})\end{array}$ & $\mathrm{pI}$ & $\begin{array}{l}\text { Primary } \\
\text { accession } \\
\text { number }\end{array}$ & $\begin{array}{l}\text { No. peptides } \\
\text { matched }\end{array}$ & $\begin{array}{l}\text { Percent } \\
\text { sequence } \\
\text { coverage }\end{array}$ & $\begin{array}{l}\text { MASCOT } \\
\text { score }\end{array}$ & $\begin{array}{l}\text { ProFound } \\
\text { expectation } \\
\text { score }\end{array}$ \\
\hline 1 & Afamin precursor & 69.02 & 5.64 & P43652 & 11 & 17 & 112 & - \\
\hline 2 & Afamin precursor & 69.02 & 5.64 & P43652 & 11 & 17 & 104 & - \\
\hline 3 & Afamin precursor & 69.02 & 5.64 & P43652 & 11 & 17 & 104 & - \\
\hline 4 & Afamin precursor & 69.02 & 5.64 & P43652 & 11 & 17 & 104 & - \\
\hline 11 & Fibrin beta & 51.37 & 8.3 & gi 223002 & 7 & 19.7 & - & 0.028 \\
\hline 13 & $\begin{array}{l}\text { Vitamin D-binding protein } \\
\text { precursor }\end{array}$ & 52.93 & 5.4 & P02774 & 6 & 15 & 55 & - \\
\hline 14 & $\begin{array}{l}\text { Vitamin D-binding protein } \\
\text { precursor }\end{array}$ & 52.93 & 5.4 & P02774 & 11 & 19 & 86 & - \\
\hline 15 & $\begin{array}{l}\text { Apolipoprotein A_IV } \\
\text { precursor }\end{array}$ & 45.37 & 5.28 & P06727 & 21 & 50 & 243 & - \\
\hline 16 & $\begin{array}{l}\text { Apolipoprotein A_IV } \\
\text { precursor }\end{array}$ & 45.37 & 5.28 & P06727 & 23 & 48 & 214 & - \\
\hline 17 & $\begin{array}{l}\text { Chain D retinol binding } \\
\text { protein with transthyretin }\end{array}$ & 12.98 & 5.30 & gi 4558178 & 4 & 51.3 & - & 0.001 \\
\hline 18 & Transthyretin precursor & 15.88 & 5.70 & P02766 & 6 & 41 & 100 & - \\
\hline 19 & Apolipoprotein A_I precursor & 30.76 & 5.56 & P02647 & 19 & 53 & 188 & - \\
\hline 20 & Apolipoprotein A I precursor & 30.76 & 5.56 & P02647 & 15 & 51 & 131 & - \\
\hline
\end{tabular}


Table 4 Protein characterization of proteins up-regulated

\begin{tabular}{|c|c|c|c|c|c|c|c|c|}
\hline Spot No. & Identity & $\begin{array}{l}\mathrm{M}_{\mathrm{r}} \\
(\mathrm{kDa})\end{array}$ & $\mathrm{pI}$ & $\begin{array}{l}\text { Primary } \\
\text { accession } \\
\text { number }\end{array}$ & $\begin{array}{l}\text { No. of } \\
\text { peptides } \\
\text { matched }\end{array}$ & $\begin{array}{l}\text { Percent } \\
\text { sequence } \\
\text { coverage }\end{array}$ & $\begin{array}{l}\text { MASCOT } \\
\text { score }\end{array}$ & $\begin{array}{l}\text { ProFound } \\
\text { expectation } \\
\text { score }\end{array}$ \\
\hline 1 & Ceruoplasmin precursor & 122.1 & 5.44 & P00450 & 16 & 18 & 118 & - \\
\hline 2 & Complement $\mathrm{C} 3$ precursor & 187.1 & 6.02 & P01024 & 12 & 10 & 67 & - \\
\hline 3 & Complement $\mathrm{C} 3$ precursor & 187.1 & 6.02 & P01024 & 8 & 7 & 56 & - \\
\hline 4 & $\begin{array}{l}\text { Complement factor B } \\
\text { preproprotein }\end{array}$ & 85.48 & 6.67 & $\mathrm{P} 00751$ & 10 & 11 & 70 & - \\
\hline 5 & $\begin{array}{l}\text { Inter-alpha-trypsin inhibitor } \\
\text { heavy chain } \mathrm{H} 4 \text { precursor }\end{array}$ & 103.3 & 6.51 & Q14624 & 12 & 19 & 82 & - \\
\hline 6 & $\begin{array}{l}\text { Inter-alpha-trypsin inhibitor } \\
\text { heavy chain } \mathrm{H} 4 \text { precursor }\end{array}$ & 103.3 & 6.51 & Q14624 & 12 & 19 & 87 & - \\
\hline 7 & $\begin{array}{l}\text { Inter-alpha-trypsin inhibitor } \\
\text { heavy chain } \mathrm{H} 4 \text { precursor }\end{array}$ & 103.3 & 6.51 & Q14624 & 13 & 19 & 85 & - \\
\hline 8 & $\begin{array}{l}\text { Inter-alpha-trypsin inhibitor } \\
\text { heavy chain } \mathrm{H} 4 \text { precursor }\end{array}$ & 103.3 & 6.51 & Q14624 & 9 & 15 & 79 & - \\
\hline 9 & $\begin{array}{l}\text { Inter-alpha-trypsin inhibitor } \\
\text { heavy chain } \mathrm{H} 4 \text { precursor }\end{array}$ & 103.3 & 6.51 & Q14624 & 9 & 15 & 79 & - \\
\hline 17 & Unnamed protein product & 60.29 & 6.10 & gi 29565 & 4 & 9.1 & - & 0.009 \\
\hline 18 & $\begin{array}{l}\text { Alpha-1-antichymotrypsin } \\
\text { precursor }\end{array}$ & 47.62 & 5.33 & P01011 & 9 & 27 & 77 & - \\
\hline 19 & $\begin{array}{l}\text { Alpha-1-antichymotrypsin } \\
\text { precursor }\end{array}$ & 47.62 & 5.33 & P01011 & 9 & 31 & 95 & - \\
\hline 20 & $\begin{array}{l}\text { Alpha-1-antichymotrypsin } \\
\text { precursor }\end{array}$ & 47.62 & 5.33 & P01011 & 9 & 31 & 104 & - \\
\hline 21 & $\begin{array}{l}\text { Alpha-1-antichymotrypsin } \\
\text { precursor }\end{array}$ & 47.62 & 5.33 & P01011 & 9 & 28 & 84 & - \\
\hline 22 & Alpha-1-antitrypsin precursor & 46.71 & 5.37 & P01009 & 17 & 48 & 154 & - \\
\hline 23 & $\begin{array}{l}\text { Alpha-2-macroglobulin } \\
\text { precursor }\end{array}$ & 46.71 & 6.00 & P01023 & 10 & 8 & 61 & - \\
\hline 24 & $\begin{array}{l}\text { Alpha-2-macroglobulin } \\
\text { precursor }\end{array}$ & 46.71 & 6.00 & P01023 & 11 & 10 & 63 & - \\
\hline 26 & $\begin{array}{l}\text { Fibrinogen gamma chain } \\
\text { precursor }\end{array}$ & 51.48 & 5.37 & P02679 & 8 & 23 & 67 & - \\
\hline 27 & Alpha-1-antitrypsin precursor & 46.71 & 5.37 & P01009 & 10 & 35 & 87 & - \\
\hline 28 & Alpha-1-antitrypsin precursor & 46.71 & 5.37 & P01009 & 14 & 42 & 139 & - \\
\hline 33 & Haptoglobin precursor & 45.18 & 6.13 & P00738 & 11 & 24 & 117 & \\
\hline 34 & Haptoglobin precursor & 45.18 & 6.13 & P00738 & 11 & 24 & 107 & \\
\hline 35 & Haptoglobin precursor & 45.18 & 6.13 & P00738 & 12 & 24 & 108 & \\
\hline 36 & Haptoglobin precursor & 45.18 & 6.13 & P00738 & 13 & 24 & 108 & \\
\hline 37 & Haptoglobin precursor & 45.18 & 6.13 & P00738 & 6 & 17 & 63 & \\
\hline 38 & Haptoglobin precursor & 45.18 & 6.13 & P00738 & 10 & 24 & 96 & \\
\hline
\end{tabular}

capacity of the MARS column for haptoglobin is inadequate, and incomplete depletion is observed in our $2 \mathrm{D}$ PAGE protein profiles of cancer patient plasma (Fig. 2c).

Zhang et al. [3] clearly demonstrated that the levels of Apolipoprotein A-I and transthyretin are both down-regulated in patients with ovarian cancer, and inter-alpha trypsin inhibitor heavy chain $\mathrm{H} 4$ was up-regulated. Moore et al. [16] was able to replicate these findings, and interestingly, in our study, the expression of chain D retinol-binding protein with transthyretin was also shown to be down-regulated. Roberts et al. [17] reported that decreased levels of retinol binding protein have been shown to be associated with an increased rate of malignant transformation of the ovarian epithelium and expression may be lost as early as stage 1 and at high frequency. These findings may be critical in early stage diagnosis.

Ceruloplasmin is an important copper-protein in serum and is essential for iron transport across the cell membrane. Recent studies have reported that ceruloplasmin may be involved in cardiovascular disease [18] and pathological brain conditions including inflammatory and neurodegenerative diseases, implicating the pro-inflammatory cytokine interleukin-1beta(IL-1 $\beta$ ) [19]. Interestingly, a concurrent study in our laboratory (data not published) demonstrates 
the up-regulation of several interleukins in the serum of cancer patients compared to controls, suggesting that these cytokines may also play a crucial role in the expression of ceruloplasmin noted to be over expressed in our study. Recent authors have also shown that IL- $1 \alpha$ enhances the bio-synthesis of complement C3 and factor B [20], both of which are also up-regulated in our protein profiles of cancer patients, again, implicating the possible role of interleukins in the progression of the disease $[20,21]$.

The role of fibrinogen has been implicated in the production of cancerous cells with increased metastatic potential [22], and the over expression of fibrinogen gamma was identified in the sera of patients with pancreatic cancer and determined to be a potential tumor marker for the disease [23]. These studies further support our observations of an up-regulation of the protein in ovarian cancer.

A comparative study of unfractionated breast carcinoma and control sera also revealed that the levels of alpha-1antichymotrypsin, an acute-phase protein, were significantly higher in all breast carcinoma patients that also concur with our findings [24].

\section{Conclusion}

Immunodepletion of plasma 2D PAGE profiling increases the identification of plasma proteins affected by the presence of high-grade ovarian cancer. As such, this approach may be useful in identifying candidate biomarkers for inclusion in multi-marker tests for ovarian cancer that are of greater sensitivity and specificity than are currently available. Immunodepletion provides only an order of magnitude enrichment of residue proteins; thus, it is more likely that high-abundance, host-response proteins will be identified using this approach than tumor-specific proteins.

\section{References}

1. Fields MM, Chevlen E. Ovarian cancer screening: a look at the evidence. Clin J Oncol Nurs. 2006;10:77-81.

2. Jones MB, Krutzsch $\mathrm{H}$, Shu $\mathrm{H}$, et al. Proteomic analysis and identification of new biomarkers and therapeutic targets for invasive ovarian cancer. Proteomics. 2002;2:76-84.

3. Zhang Z, Bast RC Jr., Yu Y, et al. Three biomarkers identified from serum proteomic analysis for the detection of early stage ovarian cancer. Cancer Res. 2004;64:5882-90.

4. Kozak KR, Su F, Whitelegge JP, Faull K, Reddy S, Farias-Eisner R. Characterization of serum biomarkers for detection of early stage ovarian cancer. Proteomics. 2005;5:4589-96.

5. Ahmed N, Oliva KT, Barker G, et al. Proteomic tracking of serum protein isoforms as screening biomarkers of ovarian cancer. Proteomics. 2005;5:4625-36.

6. Ahmed N, Barker G, Oliva KT, et al. Proteomic-based identification of haptoglobin-1 precursor as a novel circulating biomarker of ovarian cancer. Br J Cancer. 2004;91:129-40.
7. Zolotarjova N, Martosella J, Nicol G, Bailey J, Boyes BE, Barrett WC. Differences among techniques for high-abundant protein depletion. Proteomics. 2005;5:3304-13.

8. Cho SY, Lee EY, Lee JS, et al. Efficient prefractionation of lowabundance proteins in human plasma and construction of a twodimensional map. Proteomics. 2005;5:3386-96.

9. Bjorhall K, Miliotis T, Davidsson P. Comparison of different depletion strategies for improved resolution in proteomic analysis of human serum samples. Proteomics. 2005;5:307-17.

10. Martosella J, Zolotarjova N, Liu H, Nicol G, Boyes BE. Reversedphase high-performance liquid chromatographic prefractionation of immunodepleted human serum proteins to enhance mass spectrometry identification of lower-abundant proteins. J Proteome Res. 2005;4:1522-37.

11. Chromy BA, Gonzales AD, Perkins J, et al. Proteomic analysis of human serum by two-dimensional differential gel electrophoresis after depletion of high-abundant proteins. J Proteome Res. 2004;3:1120-7.

12. Jerkovic L, Voegele AF, Chwatal S, et al. Afamin is a novel human vitamin E-binding glycoprotein characterization and in vitro expression. J Proteome Res. 2005;4:889-99.

13. Wu GX, Lin YM, Zhou TH, Gao H, Pei G. Significant downregulation of alpha-albumin in human hepatoma and its implication. Cancer Lett. 2000;160:229-36.

14. Cryan LM, O'Donoghue N. Integrative proteomics: structure, function, and interaction report on the 3rd joint meeting of the British Society for Proteome Research and the European Bioinformatics Institute, July 2006. Proteomics. 2006;6:5894-7.

15. Huang HL, Stasyk T, Morandell S, et al. Biomarker discovery in breast cancer serum using 2-D differential gel electrophoresis/ MALDI-ToF/ToF and data validation by routine clinical assays. Electrophoresis. 2006;27:1641-50.

16. Moore LE, Fung ET, McGuire M, et al. Evaluation of apolipoprotein A1 and posttranslationally modified forms of transthyretin as biomarkers for ovarian cancer detection in an independent study population. Cancer Epidemiol Biomark Prev. 2006;15:1641-6.

17. Roberts D, Williams SJ, Cvetkovic D, et al. Decreased expression of retinol-binding proteins is associated with malignant transformation of the ovarian surface epithelium. DNA Cell Biol. 2002;21:11-9.

18. Fox PL, Mazumder B, Ehrenwald E, Mukhopadhyay CK. Ceruloplasmin and cardiovascular disease. Free Radic Biol Med. 2000;28:1735-44.

19. di Patti MC, Persichini T, Mazzone V, Polticelli F, Colasanti M, Musci G. Interleukin-1beta up-regulates iron efflux in rat C6 glioma cells through modulation of ceruloplasmin and ferroportin1 synthesis. Neurosci Lett. 2004;363:182-6.

20. Gerritsma JS, Gerritsen AF, Van Kooten C, Van Es LA, Daha MR. Interleukin-1 alpha enhances the biosynthesis of complement $\mathrm{C} 3$ and factor B by human kidney proximal tubular epithelial cells in vitro. Mol Immunol. 1996;33:847-54.

21. Pasch MC, Van Den Bosch NH, Daha MR, Bos JD, Asghar SS, Synthesis of complement components C3 and factor B in human keratinocytes is differentially regulated by cytokines. J Invest Dermatol. 2000;114:78-82.

22. Palumbo JS, Talmage KE, Massari JV, et al. Platelets and fibrin (ogen) increase metastatic potential by impeding natural killer cell-mediated elimination of tumor cells. Blood. 2005;105:17885.

23. Bloomston M, Zhou JX, Rosemurgy AS, Frankel W, Muro-Cacho CA, Yeatman TJ. Fibrinogen gamma overexpression in pancreatic cancer identified by large-scale proteomic analysis of serum samples. Cancer Res. 2006;66:2592-9.

24. Doustjalali SR, Yusof R, Yip CH, Looi LM, Pillay B, Hashim OH. Aberrant expression of acute-phase reactant proteins in sera and breast lesions of patients with malignant and benign breast tumors. Electrophoresis. 2004;25:2392-401. 